OPEN ACCESS

Vol. 9, No. 1, April, 2021

Page. $22-33$

DOI: https://doi.org/10.21107/jaffa.v9i1.10177
JOURNAL OF AUDITING, FINANCE, AND FORENSIC ACCOUNTING

E-ISSN: 2461-0607 ISSN: 2339-2886

https://journal.trunojoyo.ac.id/jaffa

\title{
Control-Ownership Wedge and Industry Specialist Auditor
}

\author{
Aree Saeed Mustafa*
}

University of Duhok

\section{Article Info:}

Received: March 17, 2021

in revised form: April 22, 2021

Accepted: 28 April 2021

Available Online: 30 April 2021

\section{Keywords:}

Industry Specialist Auditor, controlownership wedge, Turkey

Corresponding Author:

Email: aree.mustafa@uod.ac
Abstract; This study extends agency theory by explaining the client's understanding of audit quality. This study contributes to the audit literature by examining the effect of wedge control-ownership on industry specialist auditors that have not been researched in Turkey. The interests of minority and controlling shareholders are not completely compatible. The research analysis method used a logistic regression model, finding that firms that practice a larger difference between control rights and cash flow rights tend to prefer high audit quality measures by industry specialist auditors. This study encourages regulators to improve law enforcement to enhance the role of corporate governance in Turkey to address the features of ownership-control firms and offer a suitable environment for investment and minority shareholders.

Abstrak; Studi ini memperluas teori keagenan dengan menjelaskan pemahaman klien tentang kualitas audit. Studi ini berkontribusi pada literatur audit dengan menguji pengaruh wedge control-ownership terhadap auditor spesialis industri yang belum diteliti di Turki. Kepentingan pemegang saham minoritas dan pengendali tidak sepenuhnya sesuai. Metode analisis penelitian menggunakan model regresi logistik, menemukan bahwa perusahaan yang mempraktikkan perbedaan yang lebih besar antara hak kendali dan hak arus kas cenderung lebih memilih ukuran kualitas audit yang tinggi oleh auditor spesialis industri. Studi ini mendorong regulator untuk meningkatkan penegakan hukum guna meningkatkan peran tata kelola perusahaan di Turki untuk menangani fitur-fitur firma kendali-kepemilikan dan menawarkan lingkungan yang sesuai untuk investasi dan pemegang saham minoritas. 


\section{INTRODUCTION}

This study aims to examine the influence of ownership structure on corporate governance mechanism proxy by industry specialist auditor. Corporate governance has important role to offer suitable environment for investment (Shleifer \& Vishny, 1997). It attracts great attention as a consequence of company scandals and collapses, for example, Worldcom and Enron. Organization for Economic Corporation and Development (OECD) worked to issue the code of corporate governance. It has been utilized as an international standard and guidance for corporations, policymakers, regulators and other stakeholders. The Commonwealth Association for Corporate Governance (CACG) principles is another association that has a significant impact in this area. Consistently, Basel committee also used to revise corporate governance principles which encourage banks to implement good corporate governance. In the United State (US) the Sarbanes Oxley Act was introduced in 2002 and addressed standards of accountability for management, board of directors and audit firms. In addition, the Capital Market Board of Turkey (CMBT) amended Turkey governance principles to rectify its capital market to link it to that of Europe in early 2012. Consequently, by doing this Turkey can obtain membership in the EU.

The principles of corporate governance are about effective transparency and accountability of the companies. In addition, it addresses the important role of ownership to enhance corporate governance practise and the role to shape governance practise in companies (Desender et al., 2013). In this regards, firm ownership as a significant mechanism of corporate governance has effective role in controlling and monitoring management behaviours, and ensure that managers strive to make decisions that maximise shareholders' interests. Previous literature documents that managerial ownership might assist to conform the managers interests with that of shareholders (Beekes, Pope, \& Young, 2004). Nevertheless, ownership culture in Turkey is different from that of firms operate in developed countries (Ararat, Aksu, \& Cetin, 2015; Mustafa, Che-Ahmad, \& Chandren, 2018). Managerial ownership is not common in Turkey list firms and manager compensation is fixed instead of corporations' performance-based. The ownership structure issue is the wedge which is addressing the disparity between cash flow rights and control rights that contribute to Type II Agency Problem.

In Turkey, the problem is present between majority shareholders and minority shareholders. A study conducts by Farooq and Tabine (2015) find that high ownership concentration is the most prominent factor that exacerbates agency problems. Mohammed (2019) has the same opinion that concentrated ownership exacerbates the issue of weak minority shareholders' protection in Turkey business environment. Furthermore, Santiago-Castro and Brown (2007) report a significant relationship between ownership structure and minority protection. Therefore, Turkey has a series of agency problems (Mustafa \& Che-Ahmad, 2017). In Turkey, the conflict of interest between shareholders is strongly exacerbated as a result of high level of wedge. Insider shareholders often control firms through small ownership stakes, and they reduce the power of outside-control shareholding (Mustafa, Chandren, \& Che-Ahmad, 2018). Consequently, the misalignment of interests between the insider or outsiders is commonly be resolved in the interests controlling shareholders (Barwari \& Mustafa, 2019). Topic regarding the influence of ownership on audit quality have been examined in the developed countries in many studies (Niemi, 2005; Piot, 2001). Nevertheless, as a result of different economic environment, regulation, cultural differences and the effectiveness of corporate governance the finding of those studies may not generalize in developing countries. The rest of this paper is going to address following sections, section two discuss literature review and hypothesis development, followed by section three address research methodology. Next, section four displays regression model. Section five show descriptive statistics and finally the conclusion discusses in section six. 


\section{LITERATURE REVIEW AND HYPOTHESES DEVELOPMENT}

This study hypothesis probes the relationship between Control-Ownership wedge and audit quality (measured by industry specialist auditor).

\section{Ownership Structure}

Corporate governance has a notable role in observing management activities to minimize agency problem between agent and principle, as a consequences of the segregation between ownership and management, agency problem exist (Fama \& Jensen, 1983). This provides a protected environment for investors. Desender et al. (2013) reported that board of directors' incentives to monitor management behaviour contingent on ownership structure. This study depends on agency theory and resource dependency theory to explain the relationship between control-ownership wedge and industry specialist auditor. Client incentive to monitor management activities via involvement with high audit quality is explained using two scenarios. First scenario is alignment of interest. Therefore, firms have strong impetus to select high audit quality on the basis that they work to improve the contracting terms with other parties. While, second scenario is negative entrenchment influence. Thus, clients have weak inventive to involve with high quality audit service to protect themselves from realising any substantial misstatement and reduce inherent litigation risk. A literature review for audit quality by DeFond and Zhang (2014) indicates that agency conflicts are the most notable incentive for clients' to invoke high audit quality. This exhibits that firms sustaining grave agency conflicts possess strong impetus to demand high audit quality. Prior evidence vindicates that clients' selection of the external auditor acquires from clients' preferences for auditor characteristics for instance, industry specialist auditor. Few studies support this argument because most studies vindicate that agency conflicts are considered a better explanation for clients' impetus to demand high audit quality (DeFond \& Zhang, 2014; Mustafa, Saeed, \& Mohammed, 2018). It is of interest to extend the agency theory scope to investigate further the factors enhancing the clients' demand for high audit quality, such as ownership structure. This exhibits that the demand for strong external observing via high audit quality is contingent on the ownership structure; for example, the ownership-control structure (wedge) in Turkey. Accordingly, the following hypothesis is developed to meet this study objective:

H1: Control-ownership wedge reduce client's incentive to demand industry specialist auditor.

\section{RESEARCH METHODOLOGY}

\section{Population and Sampling}

Turkey, as an emerging economy, is dominated by several families in the form of business groups. Therefore, it is prominent to test the control-ownership structure.

The sample of this study sample encompasses five fiscal years starting 2011 to 2015, and it consists of non-financial Turkish listed firms, and it comprises 146 firms. Banks and financial institutions are excluded from the sample because different regulations and corporate governance codes govern them (Zulkarnain, 2009). In order to find out the value of SPECLST_MS this study complies with Velury, Reisch, and O'reilly (2003) study to mitigate industries comprised of less than ten firms from the final sample of the study.

\section{Variable Definition and Measurement}

This study collects data for three categories, namely dependent variable, independent variable and control variables.

\section{Dependent Variable}

In this study, the dependent variable is measured by industry specialist auditor (SPECLST_MS). 


\section{Industry Specialist Auditor}

This study follows previous scholars Craswell et al. (1995) to define industry specialist auditors as the percentage of industry sales audited by an individual audit firms to the total sales of all firms in that particular industry (Velury et al., 2003). The first step used to measure SPECLST_MS index was to calculate market share of sales of particular audit firm in a particular industry. Then, total sales audited by individual audit firm divide into total sales of all firms in that particular industry. The computation of industry specialist auditor measurement is as follows:

SPECLST_MS ${ }_{i k}=\frac{\sum_{j=1}^{J_{i k t}} S A L E S_{I J K T}}{\sum_{i=1}^{I k} \sum_{j=1}^{J_{i k t}} S A L E S_{i k t t}}$

Where

$i=$ an index of the auditors $(i=\mathrm{n})$;

$j=$ an index of clients;

$K=$ an index of the industries

$I_{k}=$ the number of auditors in industry $k$ for year $t$,

$J_{i k t}=$ the number of clients audited by auditor $i$ in industry $k$ for year $t$;

$S A L E S_{I J K T}=$ the audit fees for auditor $i$ 's client $j$ for year $t$.

The following example shows how to compute auditor industry specialist. For the period 2011, for example, the total sales audited by Deloitte \& Touche (DL) in the food, beverage and tobacco industry amount 5338146014.05165 Turkey Lira (TL) and the total sales audited by all audit firms in the same industry and the same period of time amount 25281788359.155 TL. The DL market share food, beverage and tobacco, $2011=$ $5338146014.05165 / 25281788359.155=0.211$. The computation of the auditor industry market share is as in Equation (1), where the market share of the audit firms was divided by the total sales of firms in a specific industry. Table 1 includes audit firms share more than 0.10 of audited sales in each industry, and each year. In particular, in 2011, based on SPECLST_MS 10 DL is specialist in food, beverage and tobacco industry (001), textile, wearing apparel and leather industry (002) and paper and paper products, printing and publishing industry (003);

Table 1

Industry Specialist Auditor

\begin{tabular}{|c|c|c|c|c|c|c|c|c|c|c|c|c|c|c|c|c|}
\hline \multicolumn{17}{|c|}{ SPECLIST_MS $10 \%$ (by year) } \\
\hline \multicolumn{17}{|c|}{2011} \\
\hline IC & DL & EY & KPMG & GWC & JPA & GT & EW & IAPA & KI & CH & NI & RD & ÇBD & NEI & BBD & JHI \\
\hline 001 & 0.211 & 0.1389 & - & 0.357 & 0.1072 & 0.104 & - & - & - & - & - & - & - & - & - & - \\
\hline 002 & 0.205 & 0.284 & - & - & - & - & 0.284 & - & - & - & - & - & - & - & - & - \\
\hline 003 & 0.986 & - & - & - & - & - & - & - & - & - & - & - & - & - & - & - \\
\hline 004 & 0.134 & 0.498 & - & 0.267 & - & - & - & - & - & - & - & - & - & - & - & - \\
\hline 005 & 0.175 & 0.232 & - & - & - & - & - & 0.197 & 0.109 & 0.197 & - & - & - & - & - & - \\
\hline 006 & - & 0.309 & - & 0.324 & - & 0.191 & - & - & - & - & - & - & - & - & - & - \\
\hline $\begin{array}{l}007 \\
\end{array}$ & - & 0.107 & - & - & - & - & - & - & - & - & - & - & - & - & - & - \\
\hline 008 & - & - & - & - & - & 0.177 & - & - & - & - & 0.349 & - & 0.298 & - & - & - \\
\hline 009 & 0.140 & - & 0.489 & - & 0.224 & - & - & - & - & 0.106 & - & - & - & - & - & - \\
\hline \multicolumn{17}{|c|}{2012} \\
\hline$\overline{I C}$ & DL & $\mathbf{E Y}$ & KPMG & PWC & JPA & GT & EW & IAPA & KI & $\mathrm{CHI}$ & NI & RD & ÇBD & NEI & BBD & JHI \\
\hline 001 & 0.172 & 0.199 & - & 0.511 & - & - & - & - & - & - & - & - & - & - & - & - \\
\hline 002 & 0.303 & 0.443 & - & - & - & - & - & - & - & - & - & - & - & - & - & - \\
\hline$\overline{003}$ & 0988 & - & - & - & - & - & - & - & - & - & - & - & - & - & - & - \\
\hline 004 & 0.146 & 0.552 & - & 0.222 & - & - & - & - & - & - & - & - & - & - & - & - \\
\hline 005 & 0.227 & - & 0.189 & 0.283 & - & - & - & - & - & - & - & - & - & - & - & - \\
\hline 006 & - & 0.261 & - & 0.484 & - & 0.200 & - & - & - & - & - & - & - & - & - & - \\
\hline 007 & - & 0.765 & 0.105 & - & - & - & - & - & - & - & - & - & - & - & - & - \\
\hline 008 & - & - & - & - & - & 0.231 & - & - & - & - & - & 0.298 & - & - & - & - \\
\hline 009 & 0.154 & - & - & 0.520 & 0.238 & - & - & - & - & - & - & - & - & - & - & - \\
\hline
\end{tabular}




\begin{tabular}{|c|c|c|c|c|c|c|c|c|c|c|c|c|c|c|c|c|}
\hline \multicolumn{17}{|c|}{2013} \\
\hline IC & DL & EY & KPMG & PWC & JPA & GT & EW & IAPA & KI & CHI & NI & RD & ÇBD & NEI & BBD & JHI \\
\hline 001 & - & - & - & 0.643 & - & - & - & - & - & - & - & - & - & 0.153 & - & - \\
\hline 002 & 0.375 & 0.128 & - & - & - & - & - & - & - & - & - & - & - & - & 0.116 & - \\
\hline 003 & 0.987 & - & - & - & - & - & - & - & - & - & - & - & - & - & - & - \\
\hline 004 & - & 0.780 & - & - & - & - & - & - & - & - & - & - & - & - & - & - \\
\hline 005 & - & 0.158 & 0.147 & 0.252 & - & - & - & 0.201 & - & 0.185 & - & - & - & - & - & - \\
\hline 006 & - & 0.392 & - & 0.549 & - & - & - & - & - & - & - & - & - & - & - & - \\
\hline 007 & - & 0.928 & - & - & - & - & - & - & - & - & - & - & - & - & - & - \\
\hline 008 & - & - & - & 0.121 & - & 0.282 & - & - & - & - & - & 0.407 & - & - & - & - \\
\hline 009 & 0.156 & - & - & 0.525 & 0.232 & - & - & - & - & - & - & - & - & - & - & - \\
\hline \multicolumn{17}{|c|}{2014} \\
\hline IC & DL & EY & KPMG & PWC & JPA & GT & EW & IAPA & KI & CHI & NI & RD & ÇBD & NEI & BBD & JHI \\
\hline 001 & 0.487 & 0.105 & - & - & 0.207 & 0.118 & - & - & - & - & - & - & - & - & - & - \\
\hline 002 & 0.424 & 0.173 & - & - & - & - & - & - & - & - & - & - & - & - & 0.163 & - \\
\hline 003 & 0.991 & - & - & - & - & - & - & - & - & - & - & - & - & - & - & - \\
\hline 004 & - & 0.869 & - & - & - & - & - & - & - & - & - & - & - & - & - & - \\
\hline 005 & - & 0.228 & 0.165 & 0.319 & - & - & - & - & - & 0.200 & - & - & - & - & - & - \\
\hline 006 & - & 0.391 & - & 0.559 & - & - & - & - & - & - & - & - & - & - & - & - \\
\hline 007 & 0.154 & 0.865 & 0.385 & - & - & - & - & - & - & - & - & - & - & - & - & - \\
\hline 008 & - & - & - & 0.205 & - & 0.357 & - & - & - & - & 0.113 & 0.215 & - & - & - & - \\
\hline 009 & 0.259 & 0.401 & - & - & - & 0.248 & - & - & - & - & - & - & - & - & - & - \\
\hline 005 & - & 0.228 & 0.165 & 0.319 & - & - & - & - & - & 0.200 & - & - & - & - & - & - \\
\hline 006 & - & 0.391 & - & 0.559 & - & - & - & - & - & - & - & - & - & - & - & - \\
\hline \multicolumn{17}{|c|}{2015} \\
\hline IC & DL & EY & KPMG & PWC & JPA & GT & EW & IAPA & KI & CHI & NI & RD & ÇBD & NEI & BBD & JHI \\
\hline 001 & - & - & - & 0.768 & - & - & - & - & - & - & 0.133 & - & - & - & - & - \\
\hline 002 & 0.448 & 0.164 & - & - & - & - & - & - & 0.144 & - & - & - & - & - & - & - \\
\hline 003 & 0.966 & - & - & - & - & - & - & - & - & - & - & - & - & - & - & - \\
\hline 004 & 0.155 & 0.710 & - & - & - & - & - & - & - & - & - & - & - & - & - & - \\
\hline 005 & 0.271 & 0.180 & 0.121 & 0.248 & - & - & - & - & - & 0.151 & - & - & - & - & - & - \\
\hline 006 & - & 0.444 & - & 0.464 & - & - & - & - & - & - & - & - & - & - & - & - \\
\hline 007 & 0.111 & 0.532 & 0.263 & - & - & - & - & - & - & - & - & - & - & - & - & - \\
\hline 008 & - & - & - & 0.270 & - & 0.347 & - & - & - & - & - & - & - & - & - & 0.229 \\
\hline 009 & 0.164 & 0.284 & - & - & 0.221 & 0.140 & - & - & - & - & - & - & - & - & - & - \\
\hline
\end{tabular}

Industry Code: 001 (Food, beverage and tobacco); 002 (Textile, wearing apparel and leather); 003 (Paper and paper products, printing and publishing); 004 (Chemicals, petroleum rubber and plastic products); 005 (Nonmetallic mineral products); 006 (Fabricated metal products, machinery and equipment); 007 (Information technology); 008 (Construction and public work); 009 (wholesale and retail trade, hotels and restrant). Firm sales is used as the based in calculating the auditor industry expertise. DL: Deloitte; EY: Ernst \& Young; KPMG: KPMG Peat Marwick; PWC: PricewaterhouseCoopers. JPA: JPA International; GT: Grant Thornton; EW: Enterprise Worldwide; IAPA International; KI: Kreston International; CHI: Crowe Horwath International; NI: Nexia International. RD: Referans Denetim. ÇBD: Çağdaş Bağımsız Denetim SMMM A.S; NEI: Nexia International. BBD: Birleşim Bağımsız Denetim ve YMM A.Ş and JHI: JHI Association.

Ernst \& Young (EY) is specialist in chemicals, petroleum rubber and plastic products industry (004) and fabricated metal products, machinery and equipment industry (006); KPMG is specialist in retail trade, wholesale, hotels and restaurant industry (009); PricewaterhouseCoopers (PWC) is a specialist auditor in non-metallic mineral products industry (005) and 006 and Nexia International (NI) is specialist auditor in construction and public work industry (008). Only the information technology industry (007) was audited by non-specialist auditor for instance, EY.

\section{Control-Ownership Wedge as Independent Variable}

This study conjectures this kind of control-ownership (wedge) to test the influence of corporate governance to audit quality in Turkey's environment.

\section{Control-Ownership Wedge}

This study followed a study conducts in the context of Turkey by (Yurtoglu, 2003) measure WEDGE using dichotomy measurement that is equal to 1 for firm issue shares with more than one voting rights and it is equal to 0 for firms issue one class of shares. 


\section{Control Variables}

Firm size (FSIZE), leverage (LEVE) and firm age (FAGE) are the variables controlled in the statistical model to determine the cross-sectional variances in variables that affect audit quality.

\section{Firm Size}

According to the previous studies (Adeyemi \& Fagbemi, 2010; Bamber et al., 1993; Chen et al., 2005; Francis \& Wilson, 1988; Fan \& Wong, 2005; Firth \& Smith, 1992; Mohammed, 2019; Srinidhi et al., 2011; Shan, 2014; Wang et al., 2008; Zanani et al., 2008) The firm size is measure by total assets.

\section{Leverage}

This study follows other studies to define leverage as total debt divided by the total assets (Adeyemi \& Fagbemi, 2010; Defond, 1992; Eichenseher \& Shields, 1986; Firth \& Smith 1992; Hope et al., 2008, Lee et al., 2004; Menon \& Williams, 1994; Nishtiman, 2018; Reed et al. 2000; Zanani et al., 2008).

\section{Firms Age}

The previous studies have suggested that the age of a firm plays with respect to political visibility (Fama \& Jensen, 1983; Watts \& Zimmerman, 1983) as those firms that are listed longer are under great surveillance from the public and have incentives to reduce political costs. Therefore, they are more likely to engage with high audit quality (Shan, 2014). In this study, firms age (FAGE) is measured as the number of years since the firm was incorporated.

\section{Regression Model}

This study's hypothesis is tested using the following model.

SPECLST_MS $_{\text {it }}=\beta_{\mathbf{o}}+\beta_{1}$ WEDGE $_{\text {it }}+\beta_{2}$ FSIZE $_{i t} \beta_{3} L_{E V E}+\beta_{\text {it }}$ FAGE $_{\text {it }}+\varepsilon$ it. $\quad$ Model1

Where:

For each firm (i) and each year (t)

SPECLST_MS ${ }_{i t}=$ Audit quality measured by SPECLST_MS. A dichotomous variable is WEDGE $=$ Wedge used to examine the hypotheses variables related to SPECLST_MS.

FSIZE $=$ Firm size

LEVE $=$ Leverage

FAGE $=$ Firm age

$\varepsilon_{\text {it }}=$ Error term supposed to be normally scattered with constant differences.

\section{FINDINGS AND DISCUSSION}

\section{Descriptive Statistics}

Table 2 firstly lists a proxy for audit quality denote as SPECLST_MS. Next, FSIZE, LEVE and FAGE as the control variables. The mean of industry specialist auditor is 0.167 for all firms included in this study sample, the standard deviation is 0.234 , and the range is from a 0.000 minimum to a 0.984 maximum.

Table 2

Descriptive Statistic

\begin{tabular}{ccccc}
\hline Details & Mean & Min & Max & Standard Deviation \\
& & & & \\
\hline SPECLST_MS & 0.167 & 0.000 & 0.984 & 0.234 \\
\hline FSIZE & 1.904 & 1.433 & 2.608 & 1.781 \\
\hline LEVE & .4819 & 0 & 1.707 & 0.279 \\
\hline FAGE & 33.825 & 1 & 80 & 15.856 \\
\hline
\end{tabular}

Source: Processed data

The average of total assets (FSIZE) in this study sample is $(1,904)$ Turkey Lira (TL) with a standard deviation of 2.608 with a maximum of 2.608 and a minimum of 1.433 . The mean ratio of LEVE of the sample firms is 0.481 (0.279 percentage the standard deviation) with a maximum value of 1.707 and a minimum value of 0 . The mean level of 
FAGE is 33.825 with a minimum of 1 and maximum value of 80 . Univariate test and descriptive statistics for dichotomy variable control-ownership wedge are displays in Tables 3. The divergence in proportions of the binary variables between both groups of firms is explained by chi-square test. For categorical having several categories, and there is no agreed method to order those from the lowest to highest we can use chisquare test (Idre, 2017).

Table 3

Univariate Test and Descriptive Statistics for WEDGE and SPELST_MS

\begin{tabular}{cccc}
\hline & Non-WEDGE & WEDGE & Total \\
\hline Non-SPECLST_MS & 94 & 248 & 342 \\
SPECLST_MS & 211 & 171 & 382 \\
\hline Total & 305 & 418 & 724 \\
\hline Pearson chi2 $(1)=56.9964$ & $\mathrm{Pr}=0.000$ & &
\end{tabular}

Note: for categorical variables (i.e. WEDGE) (tabulate SPECLST_MS non-WEDGE, chi2) has been employed to report the chi2 and P-value.

The result of the Chi-square test ${ }^{1}$ for the distribution differences between WEDGE and non-WEDGE firms expose that industry specialist and non-specialist selection is a significant at $1 \%$ (chi2 $=56.9964 ; \mathrm{p}=0.000$ ). The findings show that the auditor choice in Turkey is influenced by the existence of WEDGE. First column shows non-WEDGE firms, the number of clients' choice specialist auditors about 94 and non-specialist auditors are about 211. The second column shows WEDGE firms and choice specialist auditor are about 171 and non-specialist auditors are about 248. Table 3 shows that companies issue more than one class of shares are more likely to select non- specialist auditor. Based on Chi-square result, it is indicating that control-ownership wedge is more likely to reduce client's incentive to demand specialist auditor. The majority of shareholders could obtain a strong ability to minimise minority shareholders rights due to negative entrenchment impact (Desender, Aguilera, Crespi-Cladera, \& GarciaCestona, 2009). Majority shareholders have adequate abilities and incentives to oversight management directly rather than engaging with external auditors and hold them accountable for actions not aligned with their wealth (Mustafa, Che-Ahmad, \& Chandren, 2018). This means that the choice of industry specialist increase with the ratio of control rights to cash flow rights, which proposed that companies with strong entrenchment impacts are more likely to demand specialist auditor. Many studies report the same argument for example, Chien et al. (2008) in the environment of Taiwan, while another study in East Asia is coming by Fan and Wong (2002). In addition, another study conducted by Ararat, Aksu, and Tansel Cetin (2015b) in Turkey's environment.

\section{Correlation Analysis}

Correlation analysis represents a preliminary statistical tool that might be used to detect any relationship between two variables before proceeding with regression analysis (Cramer \& Howitt, 2004). Spearman correlation analysis is utilized to analyses the research findings. Table 4 displays that there are no correlation coefficients value above 0.90 and this reflects that there is no sign for potential multicollinearity (Hair, Anderson, Babin, \& Black, 2010; Pallant, 2011), or even 0.80 threshold as proposed by Gujarati and Porter (2003). However, this study used panel data analysis method to solve the multicollinearity problem (Baltagi, 1998; Hsiao, 2003).

The Spearman correlation analysis in Table 4 shows the correlation between all variables of this study at the $5 \%$ level of significance in Table 4. Based on the Spearman results, WEDGE has a small correlation with SPECLST_MS $(r=-0.21)$. The inference is that WEDGE might impact the selection or non-selection of high audit quality. FSIZE

1 Chi-square test is used in order to compare the average ranks of WEDGE firms and Big4 audit firms. This test is fit for non-parametric tests for categorical variables instead of $t$ - test. A normal distribution of the mean variances is the assumption of the $t$-test. Categorical variable is one that has two or more categories and there is no intrinsic ordering to the categories. For instance, hair colour is a categorical having a number of categories (e.g. brown, blonde, red ....etc) and there is no agreed method to order those from lowest to highest. 
has a medium positive correlation with SPECLST_MS ( $r=0.34)$. The correlation between FSIZE and SPECLST_MS reflect that they move in the same direction. Table 4 shows that LEVE has an insignificant correlation with SPECLST_MS ( $r=-0.02)$. FAGE has a significant and positive correlation with SPECLST_MS ( $\mathrm{r}=0.27)$.

Table 4

Spearman Correlation ( $N=724)$

\begin{tabular}{cccccc}
\hline & $\mathbf{1}$ & $\mathbf{2}$ & $\mathbf{3}$ & $\mathbf{4}$ & $\mathbf{5}$ \\
\hline SPECLST_MS & 1 & & & & \\
\hline WEDGE & $\mathbf{- 0 . 2 1}$ & 1 & & & \\
\hline FSIZE* & $\mathbf{0 . 3 4}$ & 0.4 & 1 & & \\
\hline LEVE & -0.02 & 0.05 & 0.02 & 1 & \\
\hline FAGE $^{* *}$ & $\mathbf{0 . 2 7}$ & 0.04 & 0.04 & $\mathbf{0 . 0 9}$ & 1 \\
\hline
\end{tabular}

Notes: Two-tailed, bold $=$ Correlations are significant at $\mathrm{p}<0.05$.

*FSIZE is natural log of total assets; **FAGE is natural log of firm age

\section{Logit Regression}

The dependent variable in this study is measured by dichotomy variable (SPECLST_MS); thus, to test the impact of a set of independent variables on the dependent variable, logistic regression is used.

\section{Audit Quality (SPECLST_MS) and Control-Ownership Wedge}

To investigate the research question and meet the research objective, Hypothesis 1 explores the direct influence of wedge on clients assertion for high audit quality. According to the findings reported in Table 5, the model shows that control-ownership wedge and control variables explained $17 \%$ of the variance of the audit quality in terms of SPECLST_MS. The regression results for the SPECLST_MS displays that the relationship between control-ownership wedge and SPECLST_MS is significant at 1\% level of significance. There is an inverse but highly significant ( $t=-3.94, p=0.000$ ) relationship between wedge (WEDGE) and SPECLST_MS. The impact is given as 0.65\%, indicating that for every increase in the value of WEDGE, SPECLST_MS will decline by $0.65 \%$. Therefore, WEDGE does not support the concept of SPECLST_MS because it leads to decrease clients' incentive to demand high audit quality.

Table 5

Industry Specialist Auditor Regression Model

Model 1

\begin{tabular}{|c|c|c|c|c|}
\hline Items & 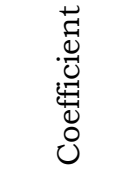 & 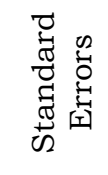 & 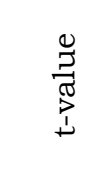 & 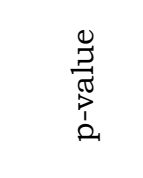 \\
\hline WEDGE & -0.065 & 0.016 & -3.94 & $0.000 * * *$ \\
\hline FSIZE & 0.041 & 0.004 & 8.89 & $0.000^{* * *}$ \\
\hline LEVE & -0.090 & 0.029 & -3.09 & $0.002^{* *}$ \\
\hline FAGE & 0.023 & 0.004 & 5.41 & $0.000 * * *$ \\
\hline $\mathrm{R}^{2}$ & \multicolumn{4}{|c|}{0.1790} \\
\hline Prob $>F$ & \multicolumn{4}{|c|}{0.000} \\
\hline
\end{tabular}

The same opinion is provided by previous studies (Choi, 2008; Kim \& Yi, 2006). The institutional setting and legal environment influence client incentive to select external auditor in the presence of high Type II Agency Problem (wedge). In the same way, Jong-hag Choi $(2007,2008)$ reports that clients tend to save their money and reduce the level of their investment in audit service in the existence of low litigation risk and weak investors protection. Directors have weak impetus to hire high quality audit in their monitoring function because of weak legal environment and institutional setting. Thus, lawsuits against directors are much less common in Turkey. The same argument is documented by previous studies that Turkey shares almost all feature of weak 
investors protection particularly minority shareholders, for instance, weak legal environment, institutional setting and accounting standards and family ownership with high concentrated ownership (e.g. wedge) (Ararat, Black, \& Yurtoglu, 2014; Yurtoglu, 2003). The result supports Hypothesis 1.

\section{CONCLUSION AND SUGGESTIONS}

This study contribution uses a control-ownership wedge and examines its effect on client request for high audit quality, especially for industry specialist auditor. The results display that wedge has a negative effect of reducing clients' incentive to involve with industry specialist auditor. Wedge weakens client ability and incentive to hire strong monitoring mechanism in term of industry specialist auditor, a result will be unfavourable for minority shareholders. The result is constant with theories proposed in this study (agency theory and resource dependency theory) and prior literature addressed in this study. Not all firms in Turkey disclosed the data about the controlownership wedge, and this represents one of the limitations of this paper. The paper recommends shareholders and regulators to be aware of enormity of the agency problem caused by the control-ownership wedge.

\section{REFERENCES}

Adeyemi, S. B., \& Fagbemi, T. O. (2010). Audit quality, corporate governance and firm characteristics in Nigeria. International Journal of Business and Management, 5(5), $169-179$.

Ararat, M., Aksu, M., \& Tansel Cetin, A. (2015). How board diversity affects firm performance in emerging markets: Evidence on channels in controlled firms. Corporate Governance: An International Review, 23(2), 83-103. https://doi.org/10.1111/corg. 12103

Ararat, M., Black, B. S., \& Yurtoglu, B. B. (2014). Corporate Governance, Business Groups, and Market Value: Time-Series Evidence from Turkey Corporate Governance, Business Groups, and Market Value: Time-Series Evidence from Turkey. (13).

Baltagi, B. H. (1998). Panel data methods. Statistics Textbooks And Monographs, 155, 291-324.

Bamber, E. M., Bamber, L. S., \& Schoderbek, M. P. (1993). Audit structure and other determinants of audit report lag: An empirical analysis. Auditing, 12(1), 1.

Barwari, A. S., \& Mustafa, A. S. (2019). Minority Shareholders Rights and Audit Quality: Empirical Evidence from Turkey. Journal of Accounting Finance and Auditing Studies (JAFAS), 4(4), 27-44. https://doi.org/10.32602/jafas.2018.003

Beekes, W., Pope, P., \& Young, S. (2004). The link between earnings timeliness, earnings conservatism and board composition: evidence from the UK. Corporate Governance: An International Review, 12(1), 47-59.

Burkart, M., Gromb, D., \& Panunzi, F. (1997). Large shareholders, monitoring, and the value of the firm. The Quarterly Journal of Economics, 693-728.

Chen, Y. M., Moroney, R., \& Houghton, K. (2005). Audit committee composition and the use of an industry specialist audit firm. Accounting \& Finance, 45(2), 217-239.

Chien, C.-C., Chen, K. Y., \& Wu, S.-Y. (2008). Corporate governance and auditor selection: evidence from Taiwan. Corporate Ownership \& Control, 492.

Choi, J. (2007). The Association between Audit Fees and the Ownership Structure. 13(2).

Cramer, D., \& Howitt, D. L. (2004). The Sage dictionary of statistics: a practical resource for students in the social sciences. Sage. 
Craswell, A. T., Francis, J. R., \& Taylor, S. L. (1995). Auditor brand name reputations and industry specializations. Journal of Accounting and Economics, 20(3), 297-322. https:// doi.org/10.1016/0165-4101(95)00403-3

Defond, M. L. (1992). The association between changes in client firm agency costs and auditor switching. Auditing, 11(1), 16.

DeFond, M., \& Zhang, J. (2014). A review of archival auditing research. Journal of Accounting and Economics, 58(2), 275-326. https://doi.org/10.1016/j.jacceco.2014.09.002

Desender, K. A., Aguilera, R. V, Crespi, R., \& García-cestona, M. (2013). When does ownership matter? Board characteristics and behavior. Strategic Management Journal, 34(7), 823-842.

Desender, K., Aguilera, R. V, Crespi-Cladera, R., \& Garcia-Cestona, M. A. (2009). Board characteristics and audit fees: Why ownership structure matters. University of Illinois at Urbana-Champaign, College of Business WP, 9-107.

Eichenseher, J. W., \& Shields, D. (1986). Corporate Capital Structure and Auditor" fit". School of Business, University of Wisconsin-Madison.

Engel, E., Hayes, R. M., \& Wang, X. (2010). Audit committee compensation and the demand for monitoring of the financial reporting process. Journal of Accounting and Economics, 49(1), 136-154.

Fama, E. F., \& Jensen, M. C. (1983). Separation of ownership and control. Journal of Law and Economics, 301-325.

Fan, J. P. H., \& Wong, T. J. (2002). Corporate ownership structure and the informativeness of accounting earnings in East Asia. Journal of Accounting and Economics, 33(3), 401-425.

Fan, J. P. H., \& Wong, T. J. (2005). Do external auditors perform a corporate governance role in emerging markets? Evidence from East Asia. Journal of Accounting Research, 43(1), 35-72.

Farooq, O., \& Tabine, S. (2015). Agency Problems and the Choice of Auditors: Evidence from the MENA Region. Review of Middle East Economics and Finance, 11(1), 7997.

Firth, M., \& Smith, A. (1992). Selection of auditor firms by companies in the new issue market. Applied Economics, 24(2), 247-255.

Francis, J. R., \& Wilson, E. R. (1988). Auditor changes: A joint test of theories relating to agency costs and auditor differentiation. Accounting Review, 663-682.

Gujarati, D. N., \& Porter, D. C. (2003). Basic Econometrics. 4th. New York: McGraw-Hill.

Hair, J. F., Anderson, R. E., Babin, B. J., \& Black, W. C. (2010). Multivariate data analysis: A global perspective (Vol. 7). Pearson Upper Saddle River, NJ.

Hope, O.-K., Kang, T., Thomas, W., \& Yoo, Y. K. (2008). Culture and auditor choice: A test of the secrecy hypothesis. Journal of Accounting and Public Policy, 27(5), 357373.

Hsiao, C. (2003). Analysis of panel data (Vol. 34). In Econometric Society Monographs. Cambridge university press.

Idre. (2017). What statistical analysis should I use? Statistical analyses using STATA. https://doi.org/http://stats.idre.ucla.edu/stata/whatstat/what-statisticalanalysis-should-i-usestatistical-analyses-using-stata/

Khalil, S., Magnan, M. L., \& Cohen, J. R. (2008). Dual-class shares and audit pricing: 
Evidence from the Canadian markets. Auditing: A Journal of Practice \& Theory, 27(2), 199-216.

Kim, J., \& Yi, C. H. (2006). Ownership structure, business group affiliation, listing status, and earnings management: Evidence from Korea. Contemporary Accounting Research, 23(2), 427-464.

Lee, H. Y., Mande, V., \& Ortman, R. (2004). The effect of audit committee and board of director independence on auditor resignation. Auditing: A Journal of Practice \& Theory, 23(2), 131-146.

Menon, K., \& Williams, J. D. (1994). The use of audit committees for monitoring. Journal of Accounting and Public Policy, 13(2), 121-139.

Mohammed, Nishtiman H. (2018). Board characteristics and firm performance: empirical evidence from turkey. Journal of Duhok University, 21(1), 423-430.

Mohammed, Nishtiman Hashim. (2019). Corporate Governance and Accounting Conservatism: The Moderating Role of Family Ownership. Finance, Accounting and Business Analysis (FABA), 1(1), 73-77.

MUSTAFA, A. S., CHANDREN, S. A., \& Che-AHMAD, A. B. (2018). Does having women on boards improve monitoring role: the impact of control - ownership wedge in turkey. Journal of Public Administration, Finance \& Law, (13), 65-77. Retrieved from http:// search.ebscohost.com/login.aspx?direct=true\&db=aph\&A $\mathrm{N}=132352466 \&$ site $=$ ehost-live

Mustafa, A S, Che-Ahmad, A., \& Chandren, S. (2018). Board diversity, audit committee characteristics and audit quality: The moderating role of control-ownership wedge. Business and Economic Horizons, 14(3), 587-614.

Mustafa, Aree Saeed, \& Che-Ahmad, A. (2017). Ownership Patterns and Control of Top 100 Turkish Listed Companies. Asian Journal of Finance \& Accounting, 9(1), 192209.

Mustafa, Aree Saeed, Che-Ahmad, A., \& Chandren, S. (2018). Board diversity, audit committee characteristics and audit quality: The moderating role of controlownership wedge. Business and Economic Horizons, 14(3), 587-614. https://doi.org/10.15208/beh.2018.42

Mustafa, Aree Saeed, Saeed, M. L., \& Mohammed, N. H. (2018). Auditor Selection in Borsa Istanbul. Audit Financiar, 16(152).

Niemi, L. (2005). Audit effort and fees under concentrated client ownership: Evidence from four international audit firms. The International Journal of Accounting, 4O(4), 303-323.

Pallant, J. (2007). SPSS survival manual: A step by step guide to data analysis using SPSS Australia. Allen \& Unwin.

Piot, C. (2001). Agency costs and audit quality: evidence from France. European Accounting Review, 10(3), 461-499.

Reed, B. J., Trombley, M. A., \& Dhaliwal, D. S. (2000). Demand for audit quality: The case of Laventhol and Horwath's auditees. Journal of Accounting, Auditing \& Finance, 15(2), 183-198.

Santiago-Castro, M., \& Brown, C. J. (2007). Ownership structure and minority rights: A Latin American view. Journal of Economics and Business, 59(5), 430-442.

Shan, Y. G. (2014). The impact of internal governance mechanisms on audit quality: a study of large listed companies in China. International Journal of Accounting, Auditing and Performance Evaluation, 1O(1), 68-90. 
https://doi.org/10.1504/IJAAPE.2014.059183

Shleifer, A., \& Vishny, R. W. (1997). A survey of corporate governance. The Journal of Finance, 52(2), 737-783.

Srinidhi, B., He, H., \& Firth, M. (2011). Choice of board governance and auditing in US family firms. CAAA Annual Conference.

Velury, U., Reisch, J. T., \& O'reilly, D. M. (2003). Institutional ownership and the selection of industry specialist auditors. Review of Quantitative Finance and Accounting, 21(1), 35-48.

Wang, Q., Wong, T.-J., \& Xia, L. (2008). State ownership, the institutional environment, and auditor choice: Evidence from China. Journal of Accounting and Economics, $46(1), 112-134$.

Yurtoglu, B. B. (2003). Corporate governance and implications for minority shareholders in Turkey. In Corporate Ownership and Control (Vol. 1). Discussion Paper, Turkish Economic Association.

Zanani, W., Abdullah, W., Shahnaz, I., \& Nurasyikin, J. (2008). The impact of board composition, ownership and CEO duality on audit quality: The Malaysian evidence.

Zulkarnain Muhamad. (2009). Audit Market Competition: Causes and Consequences. ICFAI Journal of Audit Practice, 6(1). 